\title{
Research on Development of Integrated Digital Teaching Platform in Civil Engineering in Higher Vocational Colleges
}

\author{
Xiaolin Zhang, Wei Liu, Yongping Ding, Fenghua Xia, Zhandong Wu \\ Binzhou Polytechnic, Binzhou, China \\ email:276547610@qq.com
}

Keywords: Internet, BIM, Civil Engineering, Integration, Teaching platform

\begin{abstract}
In the teaching practice of civil engineering, the Binzhou Polytechnic adheres to the principle of "deriving from school, and serving for the school”. It has exploited teaching resources by using BIM technology all at once, built a " $3+3$ " teaching system consisted of "three-stage teaching" and "three-level teaching platform" taking physical buildings on campus as a carrier, shared teaching resources by means of mobile Internet technology to make the teaching reform of civil engineering in higher vocational colleges.
\end{abstract}

\section{Research background}

Building Information Modeling (BIM), is a three-dimensional architecture model based on all information data in the constructional engineering project to stimulate all real information of the architecture virtually by digital information. In August 2016, the Ministry of Housing and Urban-Rural Development of China issued the Outline of informatization development of construction industry 2016-2020, proposed that it is necessary to promote the popularization of BIM application, and advance the "Internet Plus" cooperative working model. And currently, the "Internet+BIM" technology has become a hotspot in the construction industry.

More than 10 higher vocational colleges in Shandong has opened the BIM modeling curriculums, and BIM games and certification tests are held regularly each year in the province dominated by modeling. In the construction of IT teaching platform in colleges, inconvenient resource access often causes low rate of usage, and the teaching platform provided by professional 3D stimulation development companies also has some defects, for example, teachers cannot upgrade or maintain the resources in the model independently.

BIM technology boasts imitativeness, visualization, which can be integrated with IT teaching building of schools. The "Internet+BIM" technology can not only upgrade the teaching resources, but transform the teaching management method as well as the assessment criterion of students.

\section{Research objectives}

\subsection{Deriving from school and serving for school}

The author has selected three typical buildings on campus, and constructed a comprehensive integrated digital teaching platform modeling with Revit of BIM software and working drawing, construction organization design, settlement data, photos and videos in practical construction. The integration of teaching resources is conducive to classroom teaching and the self-learning after class. In the process, students can enter the buildings, combine physical buildings with $2 \mathrm{D}$ drawings and 3D models, learn deeply by accessing teaching resources via computers and tablet computers.

The integrated digital teaching platform not only serves for teaching, but realizes virtual exhibition of campus environment utilizing the advantages of BIM technology. Students, thus, can know campus building environment, repair and maintenance of electromechanical pipelines of campus building and smart campus by virtual tour, and teachers can access resources to take part in IT teaching skills contest, Micro-course contest, guide the technical innovation projects of college students. 


\subsection{Teaching resource pool}

Integrated digital teaching platform gathers resources into a project, taps and develops teaching resources in the project according to the teaching task. Students, through the professional curriculum group, study gradually deeply, learn engineering projects selected by the platform, understanding a single project thoroughly. As the project itself is on the campus, students can integrate the physical buildings, 2D drawing, with 3D model by virtue of Internet+BIM technology.

\subsection{Cut learning costs}

In order to ensure students are free to use software, popular software like QQ, WeCHat, Baidu Netdisk is selected in storing resources and visiting the carrier, and the BIM software is Revit, Navisworks, Glodon which has been taught in the school. In adding resources and upgrading BIM models, teachers do not have to study new software, relieving stress of both teachers and students, cutting learning costs.

\subsection{Focusing on the resource sharing on the mobile terminal}

Due to the popularization and portability of mobile phone, and full wireless network coverage on campus, integrated digital teaching platform puts resource sharing on the mobile terminal as top priority. The selected software can be applied in the mobile terminal and the PC, so students can forward documents autonomously to finish different studying tasks. The classroom test, homework, questionnaire and teaching evaluation can be achieved via APP like Duifene, and Moso Teach.

\section{Research on construction and practice of integrated digital teaching platform}

\subsection{Platform construction}

The paper takes the teaching platform of student apartment building project as an example which is completed by resource collection and collation, virtual-real synthesis, and resource sharing.

\subsubsection{Resource collection and collation}

Substantial resources in the project are accessed by collecting and editing construction photos, videos on the site.

The 2D drawing, chart and text resources are acquired by gathering and optimizing drawing (CAD/PDF) to meet the teaching needs. The construction organization design information is gathered and the aggregate schedule database is set up via the Microsoft Project.

Resources of 3D BIM model is obtained by building Revit model of student apartment building project, rendering and optimizing its Navisworks model, and constructing GGJ, GCL model of the apartment building by Glodon.

\subsubsection{Virtual-real synthesis}

The virtual video of student apartment building construction is produced by utilizing Navisworks model and aggregate schedule database. Quality roaming video of buildings is derived from the rendering software-- Lumion. Teachers will explain the knowledge combining the photos and videos of the construction and record micro-course online.

The classified resources are uploaded to the network disk so as to generate the QR code of each resource file, which is inserted in to the drawings in PDF. And its digital drawings are made to print for students as the teaching resources in the classroom. The QR code is posted on the corresponding architecture component for students to scan, and learn related knowledge, BIM model, pictures and videos via the link.

\subsubsection{Realize resource sharing}

The realization of resource sharing is explained by the course teaching of Construction Technology of Engineering (Jianzhu Gongcheng Shigong Gongyi).

Teachers will push teaching resources like virtual construction video, drawing, and micro-course 
video to students via the mobile phone before class so as to help them finish reviewing. In the class, teachers will display key points in the construction from multiple perspectives by looking through BIM models via Revit or Navisworks. After class, students will ask questions for teachers via screenshots of WeChat and QQ and teachers will assign homework via the APP in the mobile phone. Students are encouraged to browse BIM Model or enter the physical buildings to finish the homework, which will be automatically accessed and collected in real time on the cloud. After the teaching assessment, teachers will upgrade and upload teaching resources according to students' feedback, new materials, technologies and techniques.

\subsection{Application practice}

In the teaching practice, the integrated digital teaching platform, by gradual summary and improvement, has established a " $3+3$ " teaching system comprised of "three-stage teaching" and "three-level teaching platform”.

\subsubsection{Three-stage teaching model}

According to the professional course setting in the talent training program, a three-stage teaching model is devised including model learning, model construction and model use. In the early stage, browsing and learning BIM model will help students complete the introduction of the professional basic courses. And then, the opening of BIM technology course will guide students construct models independently by using BIM software. Finally, course practice will be realized according to the information about schedule, cost information with the construction cost software as shown in table 1.

Table 1 Three-stage teaching model

\begin{tabular}{|c|c|c|c|}
\hline Stage & $\begin{array}{l}\text { The first and second } \\
\text { semesters } \\
\text { Learning model }\end{array}$ & $\begin{array}{l}\text { The third semester } \\
\text { Constructing model }\end{array}$ & $\begin{array}{l}\text { The fourth and fifth } \\
\text { semesters } \\
\text { Utilizing model }\end{array}$ \\
\hline $\begin{array}{l}\text { Major } \\
\text { service } \\
\text { courses }\end{array}$ & $\begin{array}{l}\text { Construction Materials } \\
\text { Construction Map } \\
\text { Identification } \\
\text { Construction } \\
\text { technology in Real } \\
\text { Project } \\
\text { Construction CAD } \\
\text { Construction } \\
\text { Equipment, etc. }\end{array}$ & BIM Technology & $\begin{array}{l}\text { Project management } \\
\text { Project metering and } \\
\text { Valuation } \\
\text { Application of Project Cost } \\
\text { Software } \\
\text { Metering and Valuation of } \\
\text { Installation Project, etc. }\end{array}$ \\
\hline
\end{tabular}

\subsubsection{Three-level teaching platform}

In the teaching practice, the feedback of students should be gathered so as to enrich and improve the resources on the platform, and a three-level teaching platform differing in complexity, structure, has been established as shown in table 2 .

Table 2 Three-level teaching platform

\begin{tabular}{llll}
\hline level & primary & secondary & senior \\
\hline $\begin{array}{l}\text { Buildings } \\
\text { selected }\end{array}$ & $\begin{array}{l}\text { Student } \\
\text { apartment }\end{array}$ & $\begin{array}{l}\text { High-rise housing in } \\
\text { Huaqing Garden }\end{array}$ & $\begin{array}{l}\text { Yellow River Delta High-skilled } \\
\text { talent training center }\end{array}$ \\
\hline $\begin{array}{l}\text { Structural } \\
\text { style }\end{array}$ & $\begin{array}{l}\text { Frame structure } \\
\text { Floor area }\end{array}$ & $\begin{array}{l}\text { Frame-shear wall } \\
\text { structure } \\
16000 \mathrm{~m}^{2}\end{array}$ & $\begin{array}{l}\text { Frame-shear wall structure } \\
60000 \mathrm{~m}^{2}\end{array}$ \\
\hline
\end{tabular}




\section{Expansion and achievement}

\subsection{Enrich the IT teaching resources}

By utilizing teaching resources on the integrated digital teaching platform, five textbooks and digital drawings are compiled, three provincial-level resource sharing courses and one department-level resource sharing courses are constructed, and two provincial resources sharing courses are declaring.

\subsection{Promote contest, innovation, and scientific research}

Teachers, making use of resources provided by integrated digital teaching platform, take part in micro-course contests, and IT teaching contests, and win the first prize once, the third prize for two times in the IT teaching contest held by Shandong Polytechnic. At the same time, students have won the second prize and the third prize in college student scientific and technological innovation contest in the Binzhou Polytechnic and achieved outstanding results in the "Lu Ban" architectural engineering drawing contest of civil engineering of national higher vocational colleges.

\section{3 serve the society and the industry training}

Integrated digital teaching platform has not only helped students complete the virtual practical training, but launched exam training for spring entrance examination and BIM grade test, induction training of construction companies, and safety education training, which has been widely recognized by the society and the industry,

\section{Conclusion}

The research and practice of integrated digital teaching platform under the Internet+BIM technology sticks to the principle of "deriving from school and serving for school”, develop and share teaching resources by BIM technology based on the physical buildings on campus. By using mobile internet technology, a 3+3 teaching system including three-stage teaching model and three-level teaching platform has been constructed, realizing the teaching reform in civil engineering in higher vocational colleges.

\section{Acknowledgements}

Development of integrated digital teaching platform for civil construction in higher vocational colleges under the "Internet +BIM" technology (2017232)

\section{References}

[1] Wang Fang. Optimization and application of practical teaching platform for applied civil engineering of integrated BIM technology [J]. High architecture education, 2016,25 (1) :155-157.

[2] Zhang Tao. Research on the construction engineering virtual reality and practical teaching platform construction [J]. China education technical equipment, 2016,24 :52-53.

[3] Qiu Lan. Analysis on the teaching reform of civil engineering in higher vocational colleges under the background of BIM [J]. Education teaching BBS, 2016,28:135-137.

[4] Zhang Huaying. Exploration of BIM teaching in higher vocational colleges [J]. Journal of Jiamusi vocational college, 2016,1:6-7.

[5] Wang Jianchao. Application exploration of BIM technology in the teaching of professional courses in architectural colleges and universities - taking Shenyang university of architecture as an example [J]. High building education, 2017,26 (1) :161-164. 